\title{
Development of Bakiak Football (Bakfoot) as Alternative Games for Elementary School
}

\author{
Sutaryono $^{1}$, Isa Ansori ${ }^{2}$, Fajar Awang Irawan ${ }^{3}$, Dhias Fajar Widya Permana ${ }^{4}$ \\ \{sutaryonoyono@mail.unnes.ac.id ${ }^{1}$, isaansori@mail.unnes.ac.id ${ }^{2}$, fajarawang@mail.unnes.ac.id ${ }^{3}$, \\ dhiaspermana17@mail.unnes.ac.id $\left.{ }^{4}\right\}$ \\ Universitas Negeri Semarang, Indonesia ${ }^{1,2,3,4}$
}

\begin{abstract}
Bakiak was traditional game that relies on teamwork and agility training. The methods in this study was research and development using one education expertise and two learning expertise's. 12 participants were used in small-scale trial and 28 participants in the large-scale test. All participants were agreed to be participants with signing inform consent before did the test. The result found that small-trial test from education expertise was 80\% (Good), learning expertise was 81.33\% (Good) and another one was $82.67 \%$ (Good). Questionnaire result in the small-scale test was $94.16 \%$ (very good), and the average of large-scale test was $92.11 \%$ (Very good). Results and discussion in this study using small-scale trial and large-scale trial to get the data of the research. The results of small-scale trials obtained from the expert evaluation data namely, the Physical Education expertise was $80 \%$ (good), the first learning expertise was $81.33 \%$ (good), and the second learning expertise was $82.67 \%$ (good), the results of the small-scale trial in the questionnaire data found that the average percentage of the appropriate choice of answers was $94.16 \%$ (very good), the average of large-scale trial from the questionnaire data obtained the average percentage of the appropriate choice that the answers was $92.11 \%$ (very good). Conclusion: The Bakfot can be used as an alternative model of physical education through traditional games as learning activities for Elementary School students.
\end{abstract}

Keywords: Bakiak, Fooball, Tradisional Game, Physical Activity.

\section{Introduction}

Clogs or Bakiak in traditional language was a type of traditional game that trains cooperation between groups and trains the skill of each player [1]. The traditional game of Bakiak itself was a type of group play for children and would show the appearance of social aspects related to children's abilities in a group. The traditional game of Bakiak was known as footwear. Bakiak were made of strong but lightweight wood. The shape was in accordance with the soles of the feet, then given a rope made of leather or rubber [2]. As a long-form Bakiak and even more than one string, the number of ropes attached to the long Bakiak was adjusted according to the number of players. The traditional game of Bakiak was in the category of games that were playing and competing, because of the nature of the game that relies on foot dexterity and promote the cohesiveness of each participant. 
Many Physical Education teachers do not know that Bakiak can be modified both in terms of rules and tools in physical activity. Modification of traditional game using Bakiak aims to increase children's physical activity and also to make children more active as Irawan \& Nurrachmad, (2019) stated that physical activity ned more creativity, happy and without feeling bored. Researchers offer variations [4][5] in the development of traditional learning models of Bakiak and Football to be more inovative in develop new game. Development of physical education learning process in general elementary schools should be explored [6], [7], the reason why is because the student need to learn team sports such as football but also need to know traditional games such Bakiak. Teachers have never provided a model for developing between Football and Bakiak in the previous study.

Learning is an activity that involves a person in an effort to obtain knowledge, skills, recreations [8] and positive values by utilizing various sources for learning and social communities [9]. Learning can involve two parties, namely students as learners and teachers as facilitators and also sports management [10]. Learning aims to bring changes in student behavior towards a better direction this can be addressed in various forms such as changes in knowledge, understanding attitudes and behavior and skills and other aspects that exist in individual students. According to Soemintro, (2000) and Amung \& Saputra, (2000) the games were an absolute part of the child's life and the game was an integral part of the process of forming the child's personality. Furthermore Soemintro, (2000) said that the game has two meanings. First, the game was a playing activity that purely seeks pleasure without seeking win or lose. Second, the game was defining as a play activity carried out in order to find pleasure and satisfaction, but marked the win-lose results. Games were the form of activity in physical education. Therefore, the game and sport has the same tasks and goals as the duties and objectives of physical education [7]. It has been discussed that the purpose of physical education was to improve the quality of human beings, or to shape Indonesian people as a whole, which has a target for all aspects of the human person. If a child plays in the context of learning in physical education, the child will play the game with pleasure. The feeling of pleasure from the child will uncover his original personal state when they play, both in the form of original character, and habits that have shaped his personality. Thus, it can be said that by playing the games people can actualize the potential of human activities in the form of motion, attitude and behavior. From this arising situation, a physical education teacher can carry out his obligations. Based on this situation, the teacher can provide direction, correction, advice, training [11], or appropriate encouragement. Finally, the students can develop much better and can achieve the expected maturity. Hopefully, it also can be said that by playing the games we can improve the quality of children in accordance with aspects of the human person. Several problems should be solved in this study related to the physical activity and the traditional game. The purpose of this study was to facilitates the elementary student to get a chance to do physical activity using traditional games that have never existed before.

\section{Research Methods}

Bakfot was a Research and Development study. Sugiyono [12] stated that research and development was a method that used to develop or validate product for learning and education. Total participant in the small-scale trials was 12 students, and for large-scale trials was 28 students. The instrument used questionnaire and open interview after validated by the expertise from physical educator and the traditional game. All participants were agreed and full fill the 
inform consent before join the test as research study from Irawan \& Sandiyudha, [13]. The protocol of this study was observation and making the initial product, preparing the instrument, small-scale trials, revision of the first product, large-scale trials, revisions of the final product, and final product of Bakfot.

Data collection in this study based on Dwiyogo, [14] and Sugiyono [12] using observation, interview, and questionnaire. The instrument used were evaluation sheet, descriptions from interview, and questionnaire for students. The level of eligibility, quality and product acceptance were the data need in this study. Recommendation and suggestion in additional form used to complete the data from the respondent.

\section{Results and Discussion}

The stage of data collection in this study before gave the instrument to the respondent, Bakfot product has been evaluated by one expertise in traditional games and two expertize in physical education teachers. The assessment for the product used questionnaire as primer data, and open interview as seconder data.

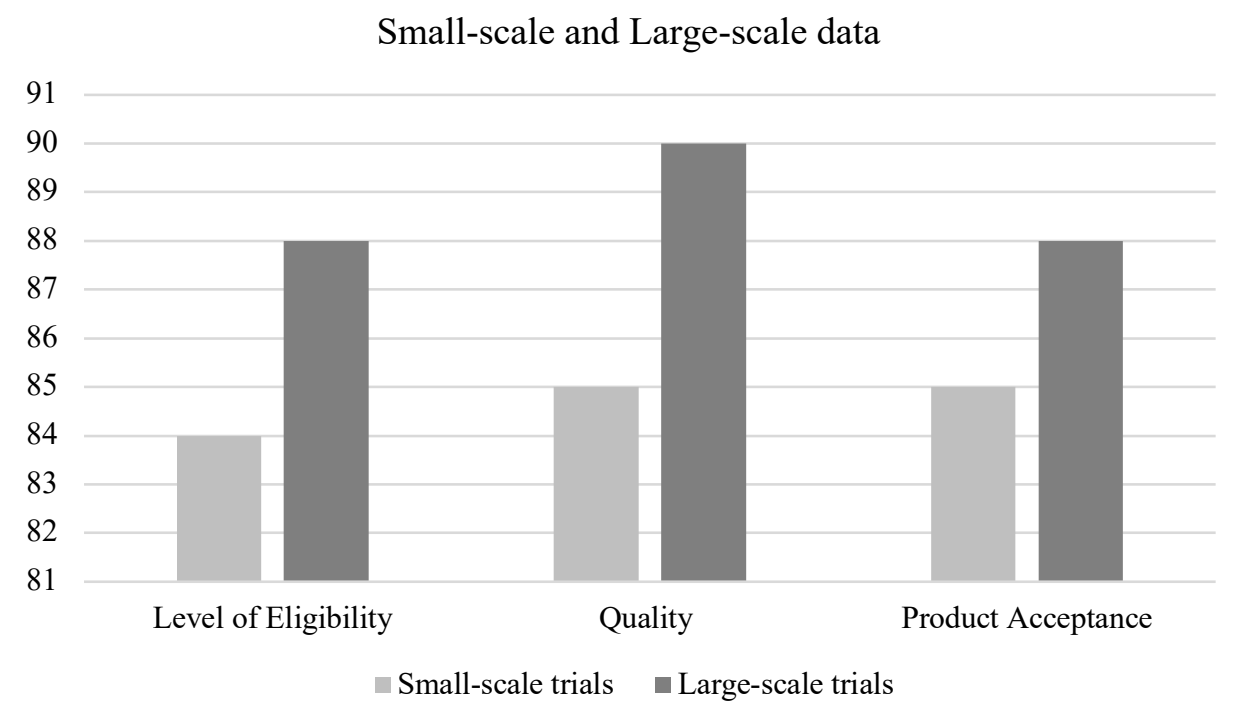

Fig. 1. Result of Bakfot study

The result of small-scale trials in level of eligibility was $84 \%$ and for large-scale trials was $88 \%$. Quality of product in small-scale trial was $85 \%$ and for large-scale trials was $90 \%$. Data for product acceptance found that small-scale trials was $85 \%$ and for large-scale trails was 88 $\%$. This small-scale trial aims to observe and identify various problems such as weaknesses, deficiencies, or the effectiveness of the product by students. Data obtained from this trial was used as a basis for product revisions before being used in large scale trials. The resulting product needs to be validated by experts in accordance with this research field. The expertise came from lecture of sport science department in traditional games expertise, and two senior teacher as physical education expertise. 
Validation was done by providing a draft model of the development product of traditional Bakfot accompanied by an evaluation sheet for traditional game experts and Elementary School Physical Education teachers. An evaluation sheet in the form of a questionnaire containing aspects of the quality of the game model, suggestions, and comments from the Physical Education experts and elementary school physical education teachers on the development model of Bakfot.

The data obtained from the filling out of the questionnaire by experts, was a guideline whether the product model of the development traditional game learning media of Bakfot can be used for large-scale trials. Based on the results of filling out the questionnaire conducted by Physical Education experts and elementary Physical Education teachers, an average in the category of " very good" in the assessment.

The description of Bakfot game was the development of the traditional game of Bakiak which was used individually and plays games like football to be played as a team by modifying both the equipment and the rules. The game was played by 3 to 5 peoples in group and each player using clogs/Bakiak and plastic balls that will be taken by players can walk in or run on the track along the 1.5 meters. The time game was 15 minutes or the first player who touch the finish line was the winner. The less time allocation it is expected that players are more active in moving. The way to plays Bakfot was to start with the draw from each players, which was the players won the draw first can gets the chance to be the first player, in one game there were the match between Bakiak and football together and the tools using Bakiak wood and the ball as the media.

Based on expert evaluations for the traditional games and education the research results from small-scale trials and the data from large-scale trials. the small-scale trial using 12 participants to know the first data about the study. After got the data and evaluation from the participants the researcher collecting the data and find the limitations of the product. The next steps was collecting the data using large-scale trials. The large-scale trials aim to determine the effectiveness of changes that have been made in expert evaluations as well as small-scale trials whether the development model of the traditional game of ball clogs can be used. Large-scale trials were conducted by fifth grade elementary school students, totaling 28 students. Largescale trial data were collected using a questionnaire. Based on large-scale trials obtained a percentage of $92.11 \%$. Based on the predetermined criteria, the model of the development of the traditional Sodakobak ball game has met the criteria very well, so it can be used for grade elementary school.

The results of the analysis of large-scale trial data obtained that the percentage of appropriate choice of answers was $93.02 \%$. Based on predetermined criteria, the traditional game development model of the Bakfot has fulfilled the criteria in very well criteria, so that from the large-scale trial this model can be used for fifth grade elementary school students. The factor that makes this model acceptable to the fifth-grade elementary school students was in the all aspects tested. The description of that results showed that more than $94 \%$ of students can practice it well. Both results from understanding the rules of the game, the application of attitude in the Bakfot game and activities in accordance with the level of growth and development. As a whole the traditional game model of Sodor Ball Gobak can be accepted by elementary school students so well, so the large-scale trials of this model can be used for fifth grade elementary school students. 


\section{Conclusion}

The conclusion of this study found that Bakfot can be used as an alternative model for physical education through traditional Bakiak learning games for elementary school students. Based on the existing criteria, the Bakfot game has fulfilled the criteria very well and suitable to be used by elementary students. Bakfot also can be one of the modification game in the development of traditional games and cultural preservation in Indonesia and also can be alternative solutions to the teacher as references in teaching of physical education in elementary school.

\section{References}

[1] F. A. Irawan and D. F. W. Permana, Permainan Rakyat Warisan Budaya Indonesia. Semarang: Fakultas Ilmu keolahragaan, Universitas Negeri Semarang, 2019.

[2] Soemintro, Permainan Kecil. Jakarta: Depdikbud, 2000.

[3] F. A. Irawan and L. Nurrachmad, "Peningkatan Softskill Dibidang Sport Recreation Melalui Pelatihan dan Pendampingan Fotografi," J. Pengabdi. Kpd. Masy., vol. 23, no. 1, pp. 32-34, 2019.

[4] S. Arikunto, "Prosedur penelitian." Jakarta: rineka cipta, 2010.

[5] S. Arikunto, Prosedur Penelitian Suatu pendekatan Praktik. 2006.

[6] Y. Bahagia and A. Suherman, Prinsip-prinsip Pengembangan dan Modivikasi Cabang Olahraga. Jakarta: Depdikbud, 2000.

[7] M. Amung and Y. M. Saputra, Perkembangan Gerak dan Belajar Gerak. Jakarta: Depdiknas, 2000.

[8] E. S. Hanani, "The Study on Value of Recreational Sports Activity of Urban Communities," $J$. Kesehat. Masy., vol. 12, no. 2, pp. 96-101, 2017.

[9] Herdiansyah, "Inovasi Gizi dan Pengembangan Modal Sosial,” Bogor, 2007.

[10] J. W. Creswell, Education Research: Planning, Conducting, and Evaluating Quantitative and Qualitative Research, Third Edit. New Jersey: Pearson Education Inc., 2008.

[11] F. A. Irawan, A. A. Putra, and L.-R. Chuang, "Physical Fitness of Adolescent Smoker," J. Kesehat. Masy., vol. 14, no. 3, pp. 398-403, 2019.

[12] Sugiyono, Metode Penelitian Kuantitatif, Kualitatif dan R\&D. Penerbit Alfabeta Bandung, 2010.

[13] F. A. Irawan and T. B. Sandiyudha, "Pengembangan Alat Bantu Push-Up ( Push-Up Counting ) Sebagai Alternatif Perangkat Kebugaran Jasmani,” J. Media Ilmu Keolahragaan Indones., vol. 8, no. 1, pp. 26-30, 2018.

[14] Wasis D Dwiyogo, Penelitian dan Pengembangan Olahraga. Malang: LemLit UNM, 2008. 